\title{
Mechanical characterization of polyester resin composite with natural fibers
}

\section{Caracterización mecánica de materiales compuestos de resina poliéster con fibras naturales}

\author{
SALAZAR-HERNÁNDEZ, Carmen $\dagger^{*}$, MENDOZA-MIRANDA, Juan Manuel, CORTES-LÓPEZ, \\ Alfredo and GONZÁLEZ-MÉNDEZ, Luis Fernando
}

Instituto Politécnico Nacional. Interdisciplinary Professional Unit of Engineering Campus Guanajuato. Av. Mineral de Valenciana No. 200 Col. Fracc. Industrial Puerto Interior, C.P. 36275 Silao de la Victoria, Guanajuato, Mexico.

ID $1^{\text {st }}$ Author: Carmen, Salazar-Hernández / ORC ID: 0000-0002-6901-2937

ID $1^{\text {st }}$ Co-author: Juan Manuel, Mendoza-Miranda / ORC ID: 0000-0003-4777-767X

ID $2^{\text {nd }}$ Co-author: Alfredo Cortes-López / ORC ID: 0000-0001-5592-1403

ID $3^{\text {rd }}$ Co-author: Luis Fernando González-Méndez / ORC ID: 0000-0003-0857-6189

\begin{abstract}
In this paper, composite materials reinforced with natural fibers were studied, such as: Jute (MC-RY) and Manta (MC-RM) as a proposal for new materials for the manufacture of a prototype for automotive defense. The materials were manufactured as laminates and characterized mechanically through stress, bending, impact and Brinell hardness index tests. The results indicated that both reinforcers improved the mechanical strength of the matrix by up to $71 \%$, as well as the impact energy absorption by $14 \%$. The mechanical properties for MC-RY determined in flexure ( $\sigma$ bending $=56 \mathrm{MPa}$, Eflection $=4.16 \mathrm{GPa}$ and $\delta$ maximum $=14 \mathrm{~mm}$ ) were used to perform an impact simulation in two different models created in SolidWork, the results indicated that the MC$\mathrm{RY}$ could be used for the construction of the defense using 3 layers of this material
\end{abstract}

Composite materials, Natural fiber, Mechanical characterization

\section{Resumen}

En este proyecto se estudiaron materiales compuestos reforzados con fibras naturales como lo son: El Yute (MCRY) y Manta (MC-RM) como propuesta de nuevos materiales para la fabricación de un prototipo de defensa automotriz. Los materiales fueron fabricados como laminados y caracterizados mecánicamente a través de ensayos de tensión, flexión, impacto e índice de dureza Brinell. Los resultados indicaron que ambos reforzantes mejoraron la resistencia mecánica de la matriz hasta en un $71 \%$, así como la absorción de energía al impacto en un 14\%. Las propiedades mecánicas para el MC-RY determinadas a flexión $(\sigma$ flexionante $=56 \mathrm{MPa}$, Eflexión $=$ $4.16 \mathrm{GPa}$ y $\delta$ máxima $=14 \mathrm{~mm}$ ) fueron empleadas para realizar una simulación de impacto en dos modelos diferentes creados en SolidWork, los resultados indicaron que el MC-RY podría emplearse para la construcción de la defensa empleando 3 capas de este material.

Material Compuesto, Fibra Natural, Caracterización Mecánica

Citation: SALAZAR-HERNÁNDEZ, Carmen, MENDOZA-MIRANDA, Juan Manuel, CORTES-LÓPEZ, Alfredo and GONZÁLEZ-MÉNDEZ, Luis Fernando. Mechanical characterization of polyester resin composite with natural fibers. Journal of Scientific and Technical Applications. 2021. 7-20:17-23.

\footnotetext{
* Correspondence to Author (Email: msalazarh@ipn.mx)

$\uparrow$ Researcher contributing as first author.
} 


\section{Introduction}

Composite materials are those made up of two or more different materials without a chemical reaction between them. In all composite material, two components are distinguished: the matrix is the majority phase and the reinforcer, which is the material that is added to improve the properties of the matrix (Figure 1) (Gibson RF, 2010; Sapuan SM, 2017, Karthigeyan P, 2017, Chawla KK, 2013).

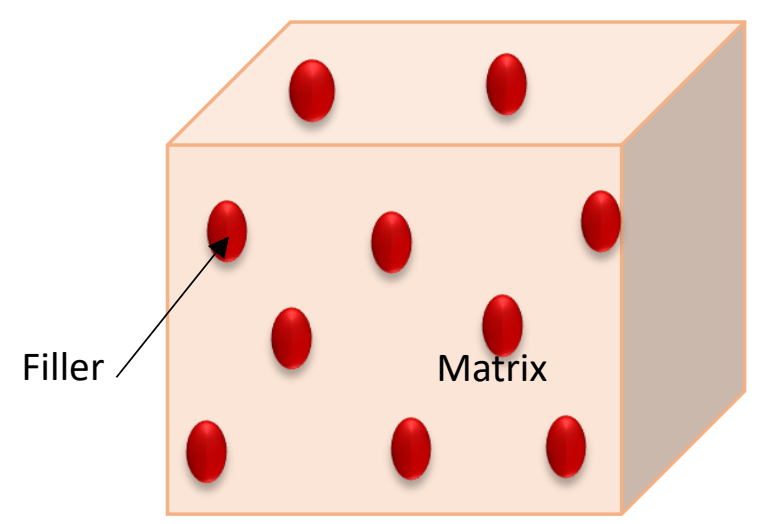

Figure 1 Composite materials structure

Thus, composite materials are the product of two or more materials that come together to give a combination with properties that cannot be obtained in the original materials. Most of the composite materials that appear in nature obtain their improved properties by the combination of two or more components that can be distinguished, some examples of this type of materials are shown in Table 1.

\begin{tabular}{|l|l|}
\hline $\begin{array}{l}\text { Natural Composite } \\
\text { Materials }\end{array}$ & $\begin{array}{l}\text { Wood, Bone, Bamboo, } \\
\text { Muscles and other tissues }\end{array}$ \\
\hline $\begin{array}{l}\text { Microcomposite } \\
\text { Materials }\end{array}$ & $\begin{array}{l}\text { Metal alloys: steels } \\
\text { Hardened thermoplastics } \\
\text { (impact polystyrene, ABS) } \\
\text { Continuous Molding Sheets } \\
\text { (SMC) } \\
\text { Reinforced thermoplastics }\end{array}$ \\
\hline $\begin{array}{l}\text { Macro Composites } \\
\text { (Engineering } \\
\text { Products) }\end{array}$ & $\begin{array}{l}\text { Galvanized steel } \\
\text { Reinforced concrete beams } \\
\text { Helicopter blades }\end{array}$ \\
\hline
\end{tabular}

Table 1 Composite materials classification

Nowadays the use of synthetic fibers and metallic materials are widely used for the manufacture of composite materials (MC) for its application in the automotive industry. However, the degradation process of these materials is very slow and causes a high accumulation of waste causing an environmental problem (Araya Navarro J.L, 2021).
In this research, the feasibility of applying natural fibers: Jute (MC-RY) and Manta (MC-RM) are carried out for the manufacture of composite materials that can be used to manufacture specific vehicle parts such as automotive defense. Thus, the research proposal is the design of a procedure that allows the manufacture of standardized specimens to carry out stress and impact tests on composite materials, as well as the manufacture of a defense as a prototype with these materials. In addition, mechanical characteristics of these composite materials and their feasibility to be used in the manufacture of a bumper is reported.

\section{Methodology}

\section{Development and mechanical characterization of composite materials}

The composites were made using epoxy resin as polymeric matrix and two natural fibers as reinforcing are used: jute fiber (MC-RY) and Manta (MC-RM). In addition, the effect of a treatment of the fiber with sodium hydroxide was investigated in order to promote a greater interaction between the reinforcer and the polymeric matrix, obtaining the materials MC$\mathrm{RY}-\mathrm{NaOH}$ and MC-RM-NaOH.

The methodology used was a modification of the proposed by Khalfallah et al. (Khalfallah M, 2014); According to Figure 2, a wooden frame was used to stretch the fiber and subsequently the polymeric resin previously mixed with $1 \%$ catalyst was applied. Finally, the material was resting for $6 \mathrm{~h}$ to remove the piece formed.

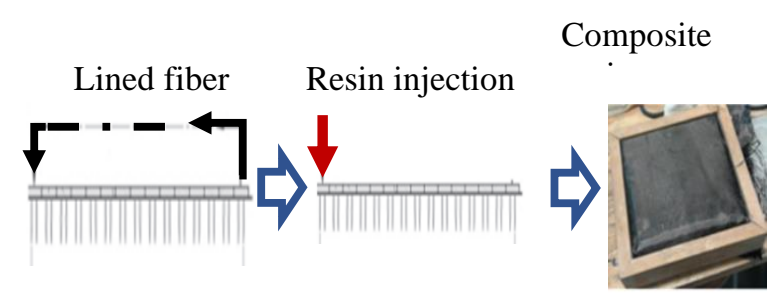

Figure 2 Pultrusion process

The composite material had the form of a sheet from which the samples was manufactured for the tensile, bending, impact and hardness tests, which they are carried out in accordance with the ASTM D3039 / D3039M / 2017, ASTM D7264 / D3039M-207, ASTM D7264 / D7264M-2015, ASTME10-15a standards. 


\section{Mechanical characterization of composite materials}

Once the specimens of the composite materials have been obtained, the mechanical tests indicated below will be carried out:

1) Hardness test.- Brinell hardness (HB) was determined using a CV-700 Universal Durometer.

2) Tension and bending test.- These tests were carried out on the Shimazum IIAutograph AGS-J universal machine.

3) Impact Test.- It was carried out using the Charpy Dilcma DIT-PC410 pendulum with an impact force of $150 \mathrm{Nm}$.

\section{Design and simulation of a bumper}

The design of the bumper prototype was done using SolidWorks 2012-64Ed software. Once the prototype (fascia) has been drawn, a static simulation of the stress distribution and deformations for the auto part was carried out.

\section{Results}

Mechanical characterization of composite materials: hardness test

Table 2 shows the results obtained from the hardness test for the polyester resin (white) and the different composite materials. All the composite materials have a $\mathrm{HB}$ greater than that of the matrix; Jute fiber being the reinforcer that increased the hardness of the polymer by a greater percentage (up to 77\%). However, this reinforcer does not generate laminates with homogeneous properties, the standard deviation of the data obtained was 33\%; while the materials reinforced with Manta presented low standard deviations $(6 \%)$.

\begin{tabular}{|l|r|r|}
\hline \multicolumn{2}{|c|}{$\begin{array}{c}\text { HB (2.5mm, 306 } \\
\mathbf{N , 3 0 s})\end{array}$} & $\begin{array}{c}\text { \% Increase of } \\
\text { HB }\end{array}$ \\
\hline White & $116.54 \pm 7.64$ & \\
\hline MC-RY & $204.83 \pm 33.35$ & 77.76 \\
\hline $\begin{array}{l}\text { MC-RY- } \\
\text { NaOH }\end{array}$ & $167.23 \pm 12.06$ & 43.49 \\
\hline MC-RM & $189.02 \pm 5.52$ & 62.19 \\
\hline $\begin{array}{l}\text { MC-RM- } \\
\text { NaOH }\end{array}$ & $178.7 \pm 6.07$ & 53.33 \\
\hline
\end{tabular}

Table 2 Brinell Hardness Index for the materials
The results shows that the Manta increase the $\mathrm{HB}$ of the matrix, although $10 \%$ less than the Brinell hardness for Jute, the Manta reinforcing agent makes it possible to obtain homogeneous materials and properties (low standard deviation) and, therefore, there would be greater control over the quality of the parts manufactured.

On the other hand, it is evident that the treatment of the fibers with sodium carbonate did not improve the properties of the material. This is probably since the fiber exposure time was not controlled with $\mathrm{NaOH}$; thus, the sodium carbonate did not increase the hydrophilicity of the fiber as expected, instead, it began to degrade it.

\section{Mechanical characterization of materials: tension test}

Figure 3 shows the stress-strain graphs obtained for the composite materials, as can be seen both the polyester resin (white) and the composite materials behaved as brittle rigid materials, without presenting plastic deformation, $\sigma_{\mathrm{y}}=\sigma_{\mathrm{u}}$. Both reinforcers increased the maximum tensile strength, forming materials with greater stiffness with a percentage of deformation in all cases lower than that observed for the polymer without reinforcer., $\% \varepsilon=3.2$. 

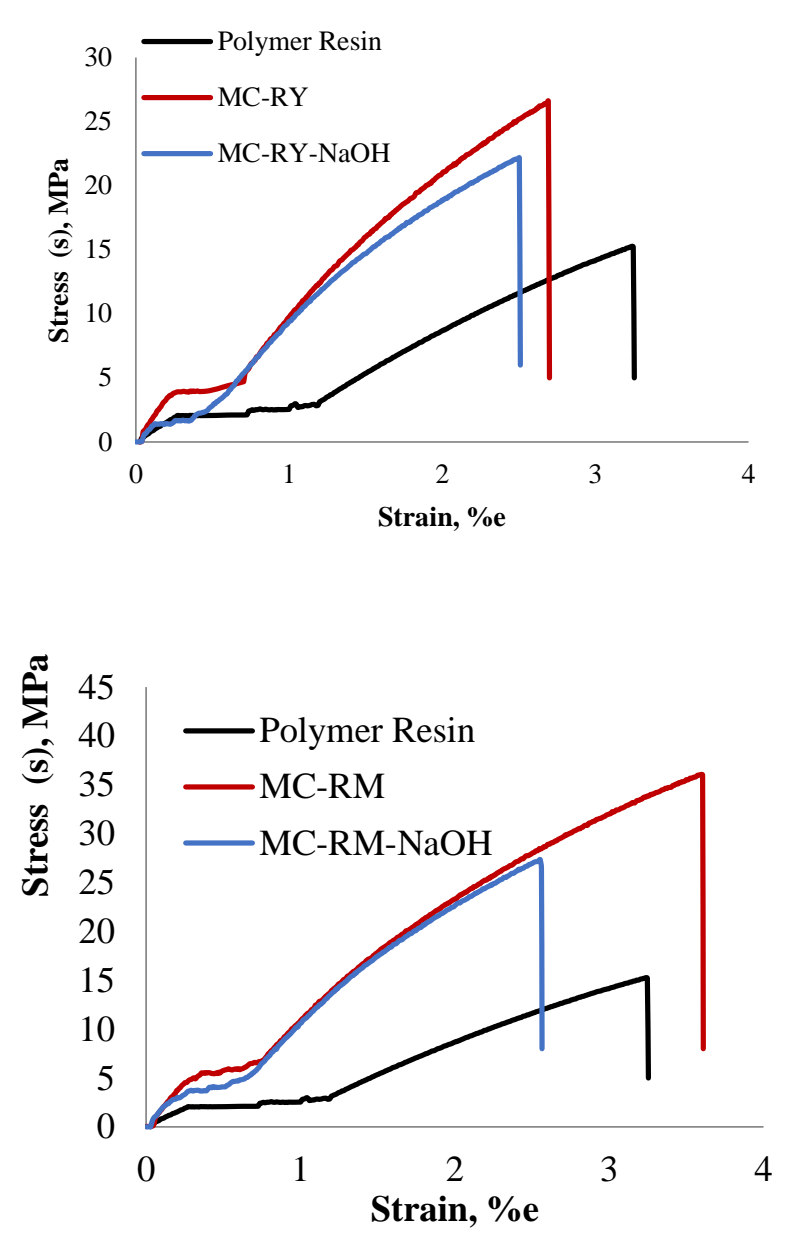

Figure 3 Tensile Stress-Strain (a) MC yute fiber reinforced (b) MC manta fiber reinforced

Table 3 summarizes different mechanical properties obtained from the stress test, such as: the modulus of elasticity (E), maximum tensile strength $\left(\sigma_{\mathrm{u}}\right)$, maximum percentage of deformation $\left(\begin{array}{lll}\% & \varepsilon\end{array}\right)$ and resilience modulus $\left(\mathrm{M}_{\text {Tenacity }}\right)$; the last one determined as the area under the stress-strain curve.

\begin{tabular}{|c|c|c|c|c|}
\hline & $\begin{array}{c}E \\
(\mathbf{G P a})\end{array}$ & $\begin{array}{c}\sigma_{u} \\
(\mathbf{M P a})\end{array}$ & $\% \varepsilon$ & $\begin{array}{c}\mathbf{M}_{\text {Tenacity }} \\
\text { (J) }\end{array}$ \\
\hline Blanco & 0.797 & 21.07 & 3.24 & 1.67 \\
\hline MC-RY & 1.07 & 26.61 & 2.69 & 0.97 \\
\hline $\begin{array}{l}\text { MC-RY- } \\
\mathrm{NaOH}\end{array}$ & 1.09 & 22.17 & 2.5 & 1.01 \\
\hline MC-RM & 2.05 & 36.06 & 3.6 & 1.69 \\
\hline $\begin{array}{l}\text { MC-RM- } \\
\mathrm{NaOH}\end{array}$ & 1.33 & 27.34 & 2.55 & 0.96 \\
\hline
\end{tabular}

Table 3 Mechanical properties from the tension test

Results shows that the reinforcers increased the elastic modulus of the polyester resin by $34-154 \%$, corroborating the results observed in the determination of Brinell hardness (HB). Both reinforcers increase the stiffness of the material; the increase in maximum tensile strength was $26-71 \%$.
However, because the reinforcers form materials with greater strength and stiffness, the capacity of deformation in the material was decreased around $20 \%$, thus, the resilience modulus is not increased.

\section{Mechanical characterization of composite materials: impact test}

The impact test using the Charpy pendulum allows the resilience modulus of the materials as energy absorbed on Impact ( $\left.E_{\text {Impact }}\right)$, the energy absorbed by the samples is shown in Figure 4 . Results shows that both reinforcers increase the capacity to absorb energy on impact; the increase in MC-RY (23\%) being greater than MC-RM (8.6\%).

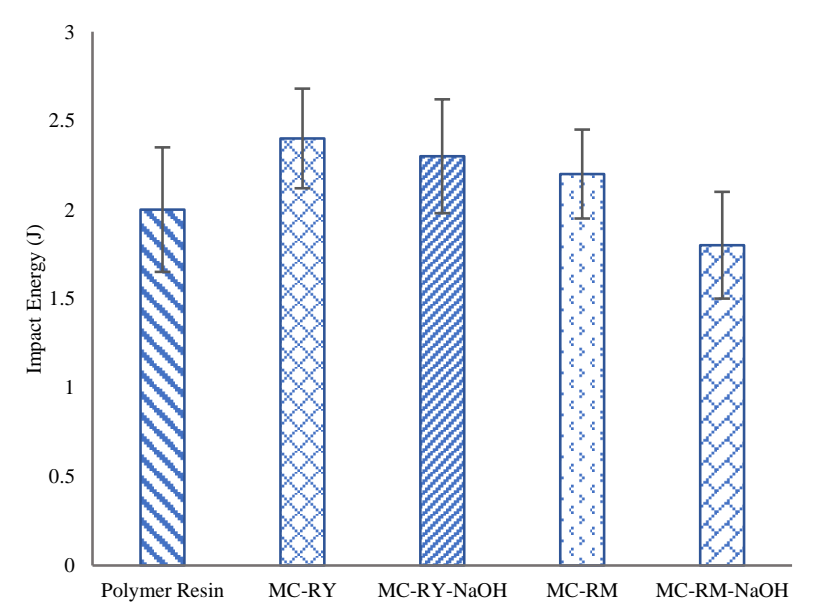

Figure 4 Energy absorbed on impact test

\section{Mechanical characterization of composite materials: bending test}

Figure 5 shows the bending curves obtained for the different materials tested, both the maximum bending force supported by the material ( $\mathrm{F}_{\text {bending }}$ ) and the deflection $(\delta)$ were obtained, which was considered as the maximum displacement recorded during the test. The maximum bending stress ( $\left.\sigma_{\text {bending }}\right)$ was measured directly from the graph, while the bending modulus ( $E_{\text {bending) was }}$ determined as the slope of the elastic zone of the curve. 

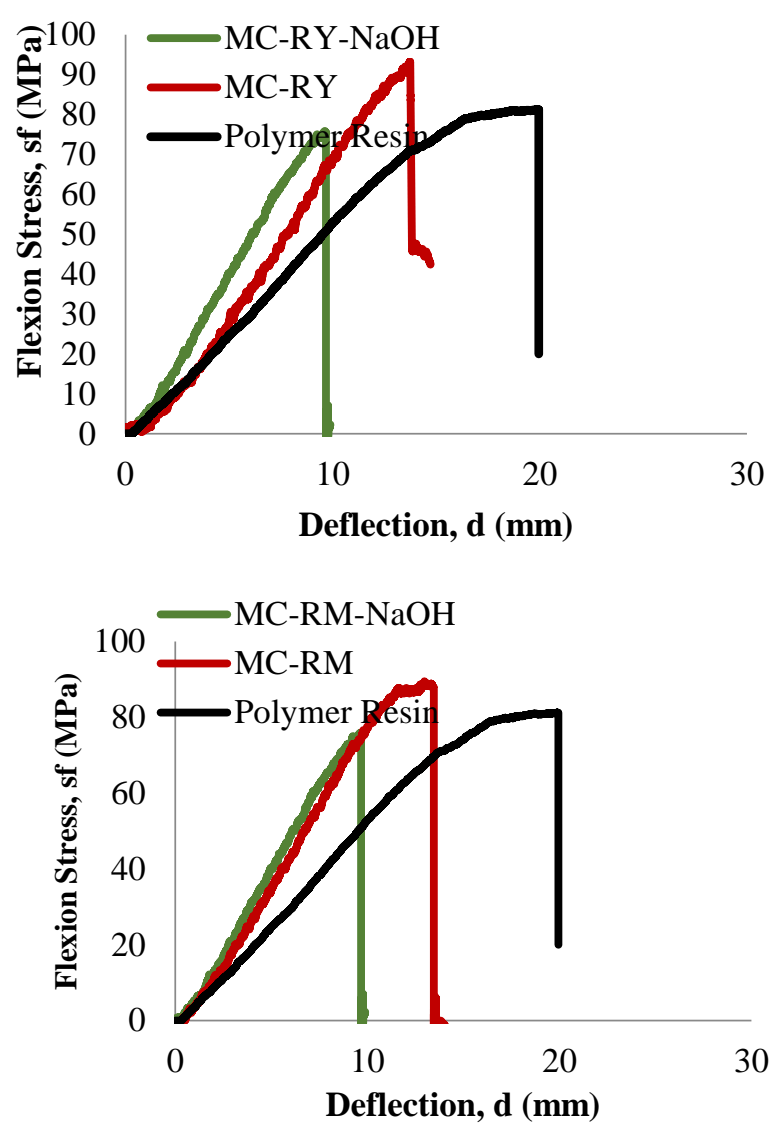

Figure 5 Bending Curve for (a) MC reinforced with Jute Fiber (b) MC reinforced with Manta

Table 4 summarizes mechanical properties obtained in the bending test for the sample materials, where both reinforcers considerably increased the bending strength, the blanket shows a bending stress of $81.12 \mathrm{MPa}$; while the MC shows values of 87 and $86 \mathrm{MPa}$, reinforced with Jute and manta respectively. In addition, both reinforcers increased the maximum bending deformation from $13 \mathrm{~mm}$ to $14 \mathrm{~mm}$.

\begin{tabular}{|c|c|c|c|}
\hline & $\begin{array}{c}\mathbf{E}_{\text {bending }} \\
\text { (GPa) }\end{array}$ & $\sigma_{\text {maximum vending }}(\mathbf{M P a})$ & $\delta \max (\mathrm{mm})$ \\
\hline White & $2.22 \pm 0.032$ & $81.12 \pm 0.103$ & $13.23 \pm 1.26$ \\
\hline MC-RY & $4.16 \pm 0.186$ & $87.24 \pm 5.62$ & $14.06 \pm 1.52$ \\
\hline MC-RY-NaOH & $3.41 \pm 0.49$ & $69.54 \pm 14.5$ & $10.77 \pm 2.64$ \\
\hline MC-RM & $3.64 \pm 0.517$ & $86.86 \pm 5.38$ & $14.19 \pm 1.64$ \\
\hline MC-RM-NaOH & $3.38 \pm 0.261$ & $65.93 \pm 8.06$ & $9.13 \pm 0.65$ \\
\hline
\end{tabular}

Table 4 Mechanical properties obtained in bending test

Figure 6 summarizes all the mechanical properties analyzed for polyester resin and natural fiber reinforced composite materials. According to these results, the natural fibers used as reinforcers considerably improve the resistance of the matrix against bending, tension, and impact stresses; However, the results shows that the difference between both reinforcers is negligible, thus, both materials can be used for the construction of automotive parts.

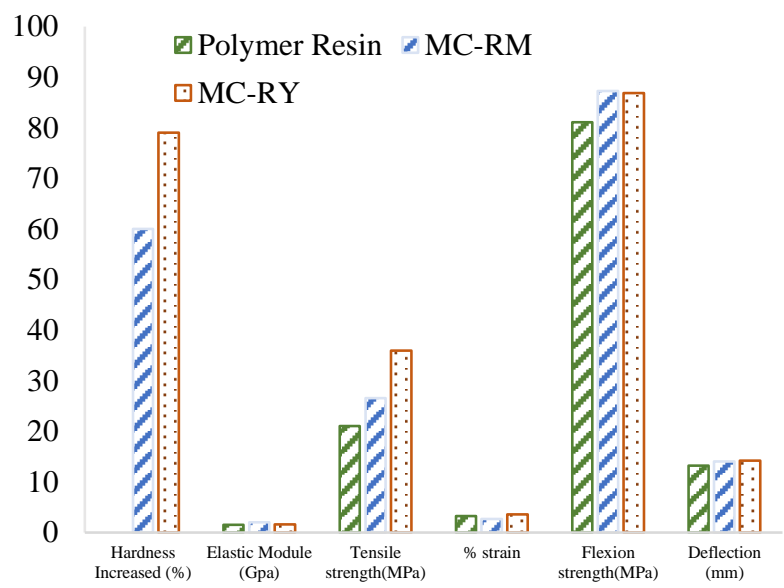

Figure 6 Summary of Mechanical Properties for MCs reinforced with natural fibres

\section{Simulation of the design of a bumper fascia}

The bumper fascia simulation was performed in SolidWorks software using the model shown in Figure 7. For the simulation two models were used changing the thickness. Model one had a thickness of $3.17 \mathrm{~mm}$, while Model two was built with a thickness of $20 \mathrm{~mm}$.

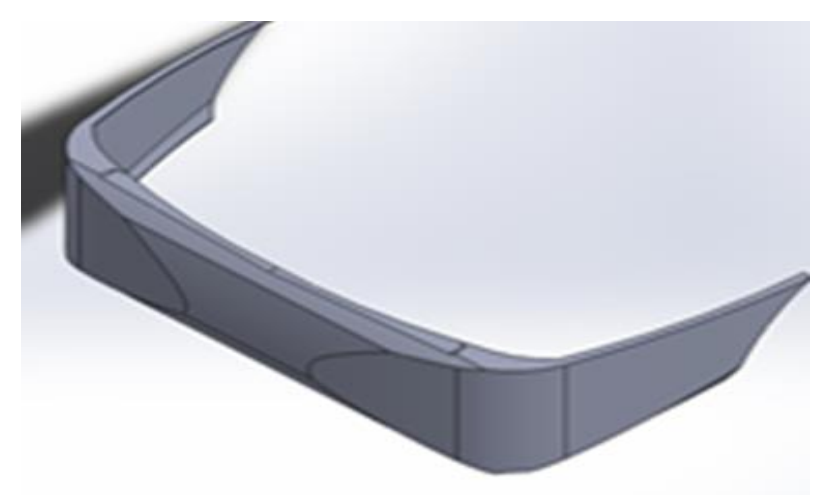

Figure 7 3-D model for a bumper fascia

Table 5 shows the mechanical properties used for the simulation, properties such as the maximum tensile strength, Poisson's modulus $(\sigma)$ and maximum deformation $(\% \varepsilon)$

\begin{tabular}{|l|r|}
\hline & \\
\hline Tensile strength, $(\sigma)$ & $87\left(\mathrm{~N} / \mathrm{mm}^{2}\right)$ \\
\hline Elastic modulus $(\mathrm{E})$ & $4156.7850\left(\mathrm{~N} / \mathrm{mm}^{2}\right)$ \\
\hline Poisson ratio $(v)$ & 0.37 \\
\hline
\end{tabular}

Table 5 Mechanical properties in the simulation using SolidWorks

On the other hand, the simulation was carried out with a static method considering frontal impact position of the bumper fascia and the distribution forces and deformations in the model was analyzed. 
Table 6 shows the different conditions used, two different forces and impact speeds. In all cases the crash duration time is $0.1 \mathrm{~s}$ and a car mass of $1262 \mathrm{~kg}$ was considered.

\begin{tabular}{|r|r|r|}
\hline & \multicolumn{1}{|c|}{ Impact force (kN) } & \multicolumn{1}{|c|}{ Impact velocity $(\mathbf{m} / \mathbf{s})$} \\
\hline Sim-1 & 70.11 & 5.56 \\
\hline Sim-2 & 105.17 & 8.33 \\
\hline
\end{tabular}

Table 6 Simulated crash conditions

Figure 8 shows the results obtained for the Model under Sim-1 conditions; similar results were obtained in all simulations. The maximum stress and deformation were observed on the collision point. Varying the impact force and / or the impact velocity, the magnitude of the stress and deformation is modified. However, in all cases due to the mechanical properties of the material the bumper fascia absorbs the impact, preventing it spreading stresses and destroying the entire piece.

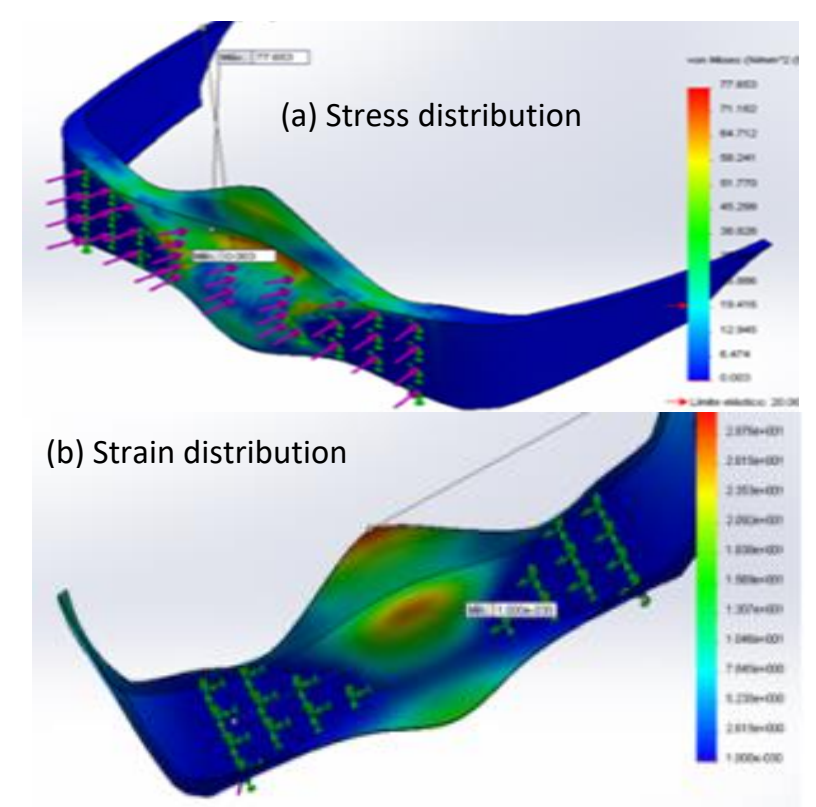

Figure 8 Impact results under conditions of Sim-1 (a) stress distribution (b) deformation distribution

Table 7 summarizes the maximum stress and strain values calculated according to the simulation conditions. The maximum stress for a layer of material is $87 \mathrm{MPa}$ and a deflection of $14 \mathrm{~mm}$. According to the results, the material fulfills with the conditions used in Model 2 and simulation conditions 1 and 2. However, under the conditions used simulation and thickness of model 1; the results shows that a layer of material could not satisfy the crash conditions.

\begin{tabular}{|c|r|r|}
\hline \multicolumn{2}{|c|}{$\begin{array}{c}\text { Impact } \\
\text { maximum stress } \\
\text { (MPa) }\end{array}$} & $\begin{array}{c}\text { Maximum } \\
\text { displacement } \\
\text { generated by impact } \\
\text { (mm) }\end{array}$ \\
\hline $\begin{array}{c}\text { Model } \\
1 \\
\text { Sim-1 }\end{array}$ & 155 & 62.7 \\
\hline $\begin{array}{c}\text { Model } \\
1\end{array}$ & & \\
Sim-2 & 232.97 & \\
\hline $\begin{array}{c}\text { Model } \\
2\end{array}$ & & \\
Sim-1 & 26.395 & \\
\hline $\begin{array}{c}\text { Model } \\
2\end{array}$ & & \\
Sim-2 & 39.592 & \\
\hline
\end{tabular}

Table 7 Results obtained from the simulation

Model 1 was built with a thickness of $3.17 \mathrm{~mm}$, because the thickness of the MC-RY laminate was $1 \mathrm{~mm}$, thus, three layers of composite material would be required for the construction of the bumper fascia proposed in Model 1. The results of the mechanical characterization of MC-RY with $3.17 \mathrm{~mm}$ thickness shows that the maximum resistance of the composite material would be $261 \mathrm{MPa}$, a greater stress than the calculated in the simulation.

\section{Conclusions}

The results from the mechanical characterization of the composite materials synthesized in this paper shows that both Jute fiber and the Manta fiber as reinforced are similar; for example, the Impact Energy was $2.43 \mathrm{~J}$ for the MC-RY and $2.14 \mathrm{~J}$ for the MC-RM.

The results from the simulation with the different forces and impact speeds indicated that in all cases the deformation and maximum stress generated in the bumper fascia does not exceed the values of the maximum stress, for the use of four layers of $3.17 \mathrm{~mm}$, which is the thickness of a conventional bumper fascia and observed deformations for the MC-RY. These results suggest that the MC-RY obtained could be used for the construction of the automotive part, having qualities and low production cost adapting to the properties that are currently required in an automotive bumper fascia, such as its impact resistance, its deformation capacity, and adding qualities such as its capacity for environmental degradation and the availability of raw material in the market. 


\section{Acknowledgements}

The authors are grateful for the financial support provided by the Secretaría de Investigación y Posgrado of the Instituto Politécnico Nacional through Project SIP- 20211679.

\section{References}

Araya Navarro J.L(2021) Producción de un biocompuesto a base de almidón termoplástico de yuca amarga (Manihot Esculenta Crantz) y nanocelulosa obtenida de rastrojo de piña (Ananas Comosus). Tesis para obtener el grado de Licenciatura en Química Industrial, Universidad Nacional de Costa Rica.

Chawla K.K. (2013) Composite Materials Science and Engineering, $3^{\mathrm{a}}$ Ed. Springer, London

Gibson R.F. (2010) A review of recent research on mechanics of multifunctional composite materials and structure, Composite Structures 92, 2793-2810

Karthigeyan P., Senthil Raja M., Hariharan R., Karthikeyan R., Prakash S (2017) Performance evaluation of composite material for aircraft industries, Materials Today Proceedings, 4, 3263-3269

Khalfallah M, Abbes B, Abbes F, Gou Y.Q, Marcel V, Duual A, Vanfleteren F, RousseayF (2014) Innovative flax tapes reinforced Acrodur biocomposites: A new alternative for automotive applications; Materials \& Desin 64:116-126.

Sapuan S.M (2017) Composite Materials, in: Composite Materials Concurrent Engineering Approach, Elsevier Ed, United Kingdom, p.p. 57-93.

Standard Test Method for Brinell Hardness of Metallic Materials. ASTME10-15a

Standard Test Method for Determining the Charpy Impact Resistance of Notched Specimens of Plastics. ASTM D110-10

Standard Test Method for Flexural Properties of Polymer Matrix Composite Materials. ASTM D7264 / D7264M-15

Standard Test Method for Tensile Properties of Polymer Matrix Composite Materials. ASTM D3039/D3039M-17

SALAZAR-HERNÁNDEZ, Carmen, MENDOZA-MIRANDA, Juan Manuel, CORTES-LÓPEZ, Alfredo and GONZÁLEZMÉNDEZ, Luis Fernando. Mechanical characterization of polyester resin composite with natural fibers. Journal of Scientific and Technical Applications. 2021 